\title{
Local Anaesthesia and Inferior Alveolar Nerve Block - A Never Ending Saga
}

\author{
Mamta Kaushik*1 and Kishore Moturi ${ }^{2}$ \\ ${ }^{1}$ Department of Conservative Dentistry and Endodontics, Army College of Dental Sciences, India \\ ${ }^{2}$ Department of Oral and Maxillofacial Surgery, Vishnu Dental College, India
}

Submission: : January 02, 2018; Published: January 11, 2018

*Corresponding author: Mamta Kaushik, Professor and Head, Department of Conservative Dentistry and Endodontics, Army College of Dental Sciences, Secunderabad, Telangana, India, Tel: 9391010325; Email: mamkaushik@gmail.com

\begin{abstract}
There is an increased incidence of pain and use of local anaesthesia in Dentistry. In the mandibular teeth the type of anaesthesia administered is the inferior alveolar nerve block. The success rate of this anaesthesia, especially in regards with restorative dentistry and endodontics is very poor. This paper reviews the various reasons for failure of the inferior alveolar nerve block and discusses various strategies used and experimented upon to increase its success rate and lead to an era of definitely painless dentistry.
\end{abstract}

Keywords: Inferior Alveolar Nerve Block; Local Anaesthesia; Irreversible Pulpitits; Pulpal Anaesthesia; Lidocaine with epinephrine

Abbreviations: IANB: Inferior alveolar Nerve Block; LA: Local Anestheisia

\section{Introduction}

Pain is defined as an "unpleasant sensory \& emotional experience associated with actual or potential t issue damage" by the International Association for the Study of Pain [1]. Dental pain is one of the most dreaded experiences cited by most people. A significant number of adults report pain when visiting the dentist [2]. One population study has shown that $73.4 \%$ of patients report pain during dental treatment [3]; while another different population study with 1086 individuals has shown that $42.5 \%$ of them have reported pain during dental treatment [4]. This is a major reason for the patient to not visit the doctor for dental treatment. Although local anaesthetic injections are an important aspect of treatment, fear of injection also deters the follow up as well as primary visit $[5,6]$. Various local anaesthetic agents (LA), topical and inject able are available to counter the dental pain and make the dental treatment a pleasant experience.

In this review article we shall briefly discuss the various agents and anaesthetic techniques used in dentistry, concentrating on failure of inferior alveolar nerve block (IANB), the reasons for failure and methods to overcome it.

\section{Anaesthetic Agents}

The agents used for local anaesthetics are either esters or amides; the difference is the means by which the body biologically transforms the active drug into one that is pharmacologically inactive. Metabolism or biotransformation of local anaesthetic is important because the overall toxicity of a drug depends on a balance between its rate of absorption in the blood stream at the site of injection and its rate of removal from the blood through the process of tissue uptake and metabolism [7]. The ester group (metabolised in plasma) contains chloroprocaine, procaine and tetracaine. The amide group (metabolised primarily in the liver) contains more commonly used local anaesthetics Articaine, Prilocaine, Lidocaine, Mepivacaine, Bupivaciane etc. [7]. Practitioners prefer the amide local anaesthetic agents to the esters as the amides produce more profound anaesthesia, more rapidly and reliably; with fewer sensitizing reactions than ester anaesthetics [8].

All clinically effective injectable LA possesses some degree of vasodilating activity. This may vary from minimal (prilocaine, mepivaciane) to significant (procaine) and also may vary with both the injection site and individual patient response. The vasodilation may lead to an increased absorption of the local anaesthetic agent from the local injection site into the Cardiovascular system, may increase the plasma levels, may increase the risk of local anaesthetic toxicity, decrease the depth and duration of anaesthesia and increase the bleeding at the site of injection [8]. Vasoconstrictors are added to local anaesthetic solution to oppose these vasodilatory actions and counter the problems associated with it. Most commonly used and accepted and available vasoconstrictor is epinephrine (used in dilution of 1:50000, 1:80000, 1:100000, 1:200000). 


\section{Routes of Administration}

Various routes of administration in the oral cavity for Maxilla are Maxillary Infiltrations, alternately Posterior Superior Alveolar Nerve Block, Middle Superior Alveolar Nerve Block (primarily for Premolars and First Molars), Intraoral Infra Orbital Nerve Block, Extraoral Infra Orbital Nerve Block, Second division Nerve Block and Palatal Anterior Superior Alveolar Nerve Block [9]. Because of the success rate of infiltrations in molars, it is the most advocated for routine restorative procedures. Mandibular anaesthesia on the other hand has a high failure rate. Because of the innervations and thickness of the mandible the techniques used are Conventional Inferior Alveolar Nerve Block, which may or may not be supplemented with a Mental Nerve Block or Incisive Nerve Block and Infiltration.

\section{Inferior Alveolar Nerve Block}

When anaesthetising the mandible for Restorative Dentistry, the failure rate varies from $23 \%$ in mandibular first molars to $58 \%$ in central incisors even thought the patient has profound lip numbness [10-12]. Clinical studies in Endodontics in patients with irreversible pulpitis have found success (mild or no pain upon Endodontic Access or Initial instrumentation) with IANB between $15 \%-57 \%$ of time [13-16]. Why does mandibular anaesthesia fail for both healthy pulp and even more for diseased pulp?

\section{Various suggested reasons are:}

Psychological: Anxiety and Fear It was found that anxious patients feel more pain than less anxious patients [5,6]. In addition to overestimation of anticipated pain [17], anxious patients also have reduced pain tolerance [18].

Anatomical: Accessory Innervation by the Mylohyoid Nerve: A Clinical and Anatomic study suggests that mylohyoid nerve is the accessory nerve which may be responsible for the failure of mandibular anaesthesia. But various studies $[19,20]$ to validate this have proved that the mandibular anaesthesia failed even though the mylohyoid nerve was properly anaesthetised. Cross Innervation has also been suggested as a reason for failure but studies have proved that this happens only in the mandibular incisor region and giving contra-lateral block also doesn't help in anaesthetising these teeth [21]. Bifid Mandibular Canal [22,23] is a finding which has been suggested for failure of anaesthesia in the mandible, however this needs further investigation.

Iatrogenic: Accuracy of the Injection: It has been theorized that an inaccurate injection may contribute to failure of the mandibular anaesthesia. This has again been countered by various studies using ultrasound [24], peripheral nerve stimulators [25] as well as radio opaque dyes [26,27]. Once lip numbness is achieved, failure of pulpal anaesthesia is not due to inaccuracy of injection for the IANB. Depth of Needle Placement for IANB [25] ranging between 17- $20 \mathrm{~mm}$ seems not to affect the failure of IANB, neither does the Needle Deflection [28], or orientation of the Needle Bevel [29].
Pathological: For diseased teeth or teeth exhibiting irreversible pulpitis, aside from the ones cited above, a few more theories have been suggested. Lowered $\mathrm{pH}$ of inflamed tissue reduces the amount of base form of the anaesthetic to penetrate the nerve membrane [30]. When local anaesthetic is injected at a physiologic $\mathrm{pH}$, the anaesthetic dissociates and equilibrium is established:

\section{Base / $H+\leftrightarrow$ Base $+H+$}

The uncharged basic form is an active form of local anaesthetics. The pKa of the anaesthetic describes the amount of uncharged form versus cationic is present at a given $\mathrm{pH}$. Local anaesthetics have pKas ranging from 7.7 to 8.9. As the $\mathrm{pH}$ of the surrounding tissues decreases during inflammation, the equilibrium shifts and there is less availability of the uncharged base form of LA [31]. There is less ionised form within the nerve to attain anaesthesia [32]. This may explain the failure with infiltrations but with IANB it doesn't explain the failure as the injection site is very far away from the place of local inflammation.

Nerves arising from inflamed tissue have altered the resting potentials and decreased excitability thresholds [30]. Substances released from inflamed tissues change the functional activity of the neurons and also alter their structural properties [32]. There is also a suggestion that terminals of peripheral nerves sprout into areas of inflammation in the dental pulp and periapical tissue [33]. Another theory, tetrodotoxin-resistant (TTX-r) class of sodium channels have been shown to be resistant to the action of local anaesthetics [30,32]. There is evidence of increased expression of sodium channels in pulps diagnosed with irreversible pulpitis. TTX-resistant class of sodium channels represents a logical mechanism for local anaesthetic failures; the channels are relatively resistant to lidociane, they are expressed on nociceptors, and their activity is increased with inflammation [32]. These and many more create a perplexing situation for the operator when his/her IANB doesn't work for restorative dentistry and endodotnics.

\section{Methods to Improve Efficacy of IANB}

There is a lot of deliberation on various methods to improve the efficacy of the LA in a case of IANB. Various methods have been suggested and experimented upon for improving the efficacy of the anaesthetic solution for IANB: For Anxiety and Fear, oral conscious sedation with triazolam [34], and aromatherapy [35] did not improve pain control in anxious patients. Educating the patient about the advances in pain management and countering the fear and anxiety comprises a large part in the dental practice. Positive and professional attitude of the doctor, his caring attitude and avoiding defensiveness aid in patient satisfaction despite of the pain [36,37]. Conscious sedation with nitrous oxide has conflicting reports on its effectiveness with painful procedures [38].

Alternative anaesthetic agent, other than the commonly used lidocaine. Various other anesthetic solutions are available and 
have been tried and experimented over the years. Mepivacaine and Prilocaine either plain or with vasoconstrictors did not improve the success of an IANB for achieving pulpal anaesthesia $[39,40]$. Combinations of plain solutions of Mepivacaineo or Prilocaine with 2\% lidocaine with 1:100,000 epinephrine also have not yielded any better success when compared to $2 \%$ lidocaine with 1:100,000 epinephrine [39]. Though in medical conditions where epinephrine/vasoconstrictors are contraindicated, plain 3\% mepivacaine may be a safe alternative to $2 \%$ lidocaine with $1: 100,000$ epinephrine. But as a plain solution there will be vasodilation and these drugs should be used with caution and should not be used in large amounts [41].

Articaine - after a lot of controversy surrounding it, articaine gained a reputation of being a drug with improved anaesthetic efficacy [42]. However, the available literature suggests that for an IANB, articaine is as effective as any other local anaesthetic agent $[43,44]$. Premedication with a oral non steroidal antiinflammatory drugs have been experimented and found to be moderately effective. Not strong enough to conclusively support the premedication for success of IANB [45].

Alternate Injection Locations - Higher injection sites which are used by the Gow-Gates or Vazirani-Akinosi techniques though suggested, are not more successful than conventional IANB technique [46]. Increasing the volume of the anaesthetic solution [47], form $1.8 \mathrm{ml}$ to $3.6 \mathrm{ml}$ or Increasing/Decreasing the concentration of the vasoconstrictors [48,49] 1:50,000, $1: 80,000,1: 100,000$ or 1:200,000 epinephrine does not increase the incidence of pulpal anaesthesia with inferior alveolar nerve block. Buffering the LA with a basic agent like Sodium Bicarbonate was suggested to make it more effective. However, studies have suggested that buffering the lidocaine formulation does not increase its success for IANB [50]. Hyaluronidase [51] and Carbonated Anaesthetic solutions [52] are other tried techniques and unsuccessful techniques which offer no additional advantage of the traditional $2 \%$ lidocaine with 1:100,000 epinephrine.

\section{Successful Methods to Increase the Success of the IANB}

Supplemental Buccal infiltration of $4 \%$ articaine in addition to the conventional IANB seems to be promising for increasing the pulpal anaesthesia with IANB [13]. Supplemental intraosseous injections [53], lidocaine and mepivaciane formulations with vasoconstrictors demonstrate increases success of pulpal anaesthesia in IANB. As do supplemental intraligamentary injections of $2 \%$ lidocaine with 1:100,000 epinephrine [54].

\section{Conclusion}

Even after so much advancement in Local Anaesthetics and the failure of the IANB is one the most embarrassing and challenging situations faced by the operator in a Dental Practice. Further research is still indicated to improve the success of the inferior alveolar nerve block.

\section{References}

1. IASP Taxonomy.

2. Liddell A, Locker D (2000) Changes in levels of dental anxiety as a function of dental experience. Behav Modif 24(1): 57-68.

3. Locker D, Shapiro D, Liddell A (1996) Negative dental experiences and their relationship to dental anxiety. Community Dent Health 13(2): 8692.

4. Maggirias J, Locker D (2002) Psychological factors and perceptions of pain associated with dental treatment. Community Dent Oral Epidemiol 30(2): 151-159.

5. Van Wijk AJ, Hoogstraten J (2005) Experience with dental pain and fear of dental pain. J Dent Res 84: 947-950.

6. Van Wijk AJ, Hoogstraten J (2009) Anxiety and pain during dental injections. J Dent Res 37: 700-704.

7. Malamed SF (2013) Handbook of local anaesthesia. ( $6^{\text {th }}$ edn). St. Louis, Missouri, USA.

8. Moore PA, Hersh EV (2010) Local anaesthetics: Pharmacology and toxicity. Dent Clin North Am 54: 587-599.

9. Reader A, Nusstein J, Melissa D (2011) Successful local anaesthesia for restorative dentistry and endodontics. ( $1^{\text {st }}$ edn.) Quintessense Books.

10. Goodman A, Reader A, Nusstein J, Beck M (2006) Anaesthetic efficacy of lidocaine/meperidine for inferior alveolar nerve blocks. Anesth Prog 53: 131-139.

11. Lai TN, Lin CP, Kok SH (2006) Evaluation of mandibular block using a standardized method. Oral Surg Oral Med Oral Pathol Oral Radiol Endod 102: 462-468.

12. Clark K, Reader A, beck M, Meyers WJ (2002) Anaesthetic efficacy of an infiltration in mandibular anterior teeth following inferior alveolar nerve block. Anesth Prog 49: 49-55.

13. Haase A, Reader A, Nusstein J, Beck M, Drum M (2008) Comparing anaesthetic efficacy of articaine versus lidocaine as a supplemental buccal infiltration of the mandibular first molar after inferior alveolar nerve block. J Am Dent Assoc 139: 1228-1235.

14. Nuzum FM, Drum M, Nusstein J, Reader A, Beck M (2010) Anaesthetic efficacy of articaine for a combination labial plus lingual infiltration versus a labial infiltration in the mandibular lateral incisor. J Endod 36: 952-956.

15. Walton RE, Abbott BJ (1981) Periodontal ligament injection: a clinical evaluation. J Am Dent Assoc 103: 571-575.

16. Cohen HP, Cha BY, Spanberg LS (1993) Endodontic anaesthesia in mandibular molars: a clinical study. J Endod 19: 370-373.

17. Arnzt A, Dreesen L, de jong (1994) The influence of anxiety on pain: Attentional and attributional mediators. Pain 56: 307-314.

18. Vika M, Raadal M, Skaret E, Kvale G (2006) Dental and medical injections: Prevalence of self-reported problems among 18-yr-old subjects in Norway. Eur J Oral Sci 114: 122-127.

19. Clark S, Reader A, Beck FM, Meyers WJ (1999) Anaesthetic efficacy of the mylohyoid nerve block and combination inferior alveolar nerve block/mylohyoid nerve block. Oral Surg Oral Med Oral Pathol Oral Radiol Endod 87: 557-563.

20. Foster W, McCartney M, Reader A, Beck M (2007) Anaesthetic efficacy of buccal and lingual infiltrations of lidocaine following an inferior alveolar nerve block in mandibular posterior teeth. Anesth Prog 54: 163-169.

21. Yonchak T, Reader A, Beck M, Meyers WJ (2001) Anaesthetic efficacy of unilateral and bilateral inferior alveolar nerve blocks to determine 
cross innervations in anterior teeth. Oral Surg Oral Med Oral Pathol Oral Radiol Endod 92: 132-135.

22. Kuribayashi A, Watanabe H, Imaizumi A, Tantanapornkul W, Katakami $\mathrm{K}$, et al. (2010) Bifid mandibular canals: Cone beam computed tomography evaluation. Dentomaxillofac Radiol 39: 235-239.

23. Lew K, Townsen G (2006) Failure to obtain adequate anaesthesia associated with bifid mandibular canal: A case report. Aus Dent j 51: 86-90.

24. Hannan L, Reader a, Nist R, Beck M, Meyers WJ (1999) The use of ultrasound for guiding needle placement for inferior alveolar nerve block. Oral Surg Oral Med Oral Pathol Oral Radiol Endod 87: 658-665.

25. Simon F, Reader A, Drum M, Nusstein J, Beck M (2010) A prospective, randomised single blind study of the anaesthetic efficacy of the inferior alveolar nerve block administered with a peripheral nerve stimulator. J Endod 36: 429-433.

26. Berns JM, Sadove MS (1962) Mandibular block injection: A method of study using an injected radiopaque material. J Am Dent Assoc 65: 735745 .

27. Galbreath JC (1970) Tracing the course of the mandibular block injection. Oral Surg Oral Med Oral Pathol 30: 571-582.

28. Hochman M, Friedman (2000) In vitro study of needle deflection: A linear insertion technique versus a bidirectional rotation insertion technique. Quintessence Int 31: 33-38.

29. Steinkruger G, Nusstein J, Reader A, Beck M, Weaver J (2006) The significance of needle bevel orientation in success of inferior alveolar nerve block. J Am Dent Assoc 137: 1685-1691.

30. Potocnik I, Bajrovic F (1999) Failure of inferior alveolar nerve block in endodontics. Endod Dent Traumatol 15: 247-25.

31. Boyce RA, Kirpalani T, Mohan N (2016) Updates of topical and local anaesthesia agents. Dent Clin North Am 60: 445-471.

32. Hargreaves KM, Keiser K (2002) Local anaesthetic failue in endodontics: mechanisms and management. Endod Top 1: 26-39.

33. Byers MR, Taylor PE, Khayat BG, Kimberly Cl (1990) Effects of injury and inflammation on pulpal and periapical nerves. J Endod 16: 78-84.

34. Lindemann M, Reader A, Nusstein J, Drum M, Beck M (2008) Effect of sublingual triazolam on the success of inferior alveolar nerve block in patients with irreversible pulpitis. J Endod 34: 1167-1170.

35. Kiecolt-Glaser JK, Graham JE, Malarkey WB, Porter K, Lemeshow S, et al. (2008) Olfactory influences on mood and autonomic, endocrine, and immune function. Psychoneuroendocrinology 33: 328-339.

36. Gale EN, Carlsson SG, Ericksson A, Jontell M (1984) Effects of dentists' behaviour on patients' attitudes. J Am Dent Assoc 09: 444-446.

37. Schouten BC, Eijkman MA, Hoogstraten J (2003) Dentists' and patients' communicative behaviour and their satisfaction with the dental encounter. Community Dent Health 20: 11-15.

38. Babl Fe, Oakley E, Puspitadewi A, sharwood LN (2008) Limited analgesic efficacy of nitrous oxide for painful procedures in children. Emerg Med J 25: 717-721.

39. McLean C, Reader A, Beck M, Meyers WJ (1993) An evaluation of $4 \%$ prilocaine and $3 \%$ mepivacaine compared with $2 \%$ lidocaine
(1:100000 epinephrine) for inferior alveolar nerve block. J Endod 19: 146-150.

40. Hinkley SA, Reader A, Beck M, Meyers WJ (1991) An evaluation of $4 \%$ prilocaine with 1:200,000 epinephrine and 2\% mepivacaine with 1:20,000 levonordefrin compared with $2 \%$ lidocaine with 1:100,000 epinephrine for inferior alveolar nerve block. Anesth Prog 38: 84-89.

41. Chin KL, Yagiela JA, Quinn Cl, Henderson KR, Duperon Df (2003) Serum mepivacaine concentrations after intraoral injections in young children. J Calif Dent Assoc 31: 757-764.

42. Malamed S, Gagnon S, Leblanc D (2000) Efficacy of articaine: a new amide local anaesthetic. J Am Dent Assoc 131: 635-642.

43. Miksell P, Nusstein J, Reader A, Beck M, Weaver J (2005) A comparison of articaine and lidocaine for inferior alveolar nerve blocks. J Endod 31: $265-270$.

44. Tortamano IP, Siviero M, Costa CG, Buscariolo IA, Armonia PL (2009) A comparison of the anaesthetic efficacy of articaine and lidocaine in patients with irreversible pulpitis. J Endod 35: 165-168.

45. Lapidus D, Goldberg J, Hobbs EH, Ram S, Clark GT, et al. (2016) Effect of premedication to provide analgesia as a supplement to inferior alveolar nerve block in patients with irreversible pulpitis. J Am Dent Assoc 147(6): 427-437.

46. Goldberg S, Reader A, Drum M, Nusstein J, Beck M (2008) Comparison of the anaesthetic efficacy of the conventional inferior alveolar, GowGates, and Vazirani-Akinosi techniques. J Endod 34: 1306-1311.

47. Nusstein J, Reader A, Beck FM (2002) Anaesthetic efficacy of different volumes of lidocaine with epinephrine for inferior alveolar nerve block. Gen Dent 50: 372-377.

48. Dagher FB, Yared GM, Machtou P (1997) An evaluation of $2 \%$ lidocaine with different concentrations of epinephrine for inferior alveolar nerve block. J Endod 23: 178-180.

49. Tofoli GR, Ramacciato JC, de Oliveira PC, Volpata MC, Groppo FC, et al. (2003) Comparison of the efficacy of $4 \%$ articaine associated with $1: 100,000$ or 1:200,000 epinephrine in inferior alveolar nerve block. Anesth Prog 50: 164-168.

50. Whitcomb M, Drum M, Reader A, Nusstein J, Beck M (2010) A prospective randomised double blind study of the anesthetic efficacy of sodium bicarbonate buffered $2 \%$ lidocaine with 1:100,000 epinephrine in inferior alveolar nerve blocks. Anesth Prog 57: 59-66.

51. Ridenour S, Reader A, Beck M, Weaver J (2001) Anaesthetic efficacy of a combination of hyaluronidase and lidocaine with epinephrine in inferior alveolar nerve blocks. Anesth Prog 48: 9-15.

52. Chaney MA, Kerby R, Reader A, Beck FM, Meyers MJ, et al. (1991) An evaluation of lidocaine hydrocarbonate compared with lidocaine hydrochloride for inferior alveolar nerve block. Anesth Prog 38: 212216.

53. Dunbar D, Reader A, Nist R, Beck M, Meyers BJ (1996) Anaesthetic efficacy of intraosseous injection after an inferior alveolar nerve block. J Endod 22: 481-486.

54. Childers M, Reader A, Nist R, Beck M, Meyers BJ (1996) Anaesthetic efficacy of the periodontal ligament injection after an inferior alveolar nerve block. J Endod 22: 317-320. 
(7) This work is licensed under Creative Commons Attribution 4.0 License DOI: 10.19080/JPCR.2018.05.555652

\section{Your next submission with Juniper Publishers will reach you the below assets}

- Quality Editorial service

- Swift Peer Review

- Reprints availability

- E-prints Service

- Manuscript Podcast for convenient understanding

- Global attainment for your research

- Manuscript accessibility in different formats

( Pdf, E-pub, Full Text, Audio)

- Unceasing customer service

Track the below URL for one-step submission https://juniperpublishers.com/online-submission.php 